Review

\title{
Potential Relationship between Inadequate Response to DNA Damage and Development of Myelodysplastic Syndrome
}

\author{
Ting Zhou ${ }^{1,2}$, Peishuai Chen ${ }^{1,3}$, Jian Gu ${ }^{3}$, Alexander J. R. Bishop ${ }^{1,2,4,5}$, Linda M. Scott ${ }^{6}$, \\ Paul Hasty ${ }^{4,5,7}$ and Vivienne I. Rebel ${ }^{1,2,4,5, *}$
}

1 Greehey Children's Cancer Research Center, University of Texas Health Science Center San Antonio (UTHSCSA), 8403 Floyd Curl Drive, San Antonio, TX 78229, USA;

E-Mails: zhoubaipi@gmail.com (T.Z.); ChenP3@uthscsa.edu (P.C.); bishopa@uthscsa.edu (A.J.R.B.)

2 Department of Cellular and Structural Biology, UTHSCSA, 7703 Floyd Curl Drive, San Antonio, TX 78229, USA

3 Department of Hematology, Northern Jiangsu People's Hospital, Yangzhou 225001, China; E-Mail: gujianyz@sina.com

4 The Cancer Therapy Research Center, UTHSCSA, 7979 Wurzbach Road, San Antonio, TX 78229, USA; E-Mail: hastye@uthscsa.edu

5 Barshop Institute for Longevity and Aging Studies, UTHSCSA, Texas Research Park Campus, 15355 Lambda Drive, San Antonio, TX 78245, USA

6 The University of Queensland Diamantina Institute, Translational Research Institute, 37 Kent Street, Woolloongabba, QLD 4102, Australia; E-Mail: 1.scott3@uq.edu.au

7 Department of Molecular Medicine, UTHSCSA, 7703 Floyd Curl Drive, San Antonio, TX 78229, USA

* Author to whom correspondence should be addressed; E-Mail: rebel@uthscsa.edu; Tel.: +1-210-562-9096; Fax: +1-210-562-9014.

Academic Editor: Guillermo T. Sáez

Received: 5 November 2014 / Accepted: 22 December 2014 / Published: 5 January 2015

\begin{abstract}
Hematopoietic stem cells (HSCs) are responsible for the continuous regeneration of all types of blood cells, including themselves. To ensure the functional and genomic integrity of blood tissue, a network of regulatory pathways tightly controls the proliferative status of HSCs. Nevertheless, normal HSC aging is associated with a noticeable decline in regenerative potential and possible changes in other functions. Myelodysplastic syndrome (MDS) is an age-associated hematopoietic malignancy, characterized by abnormal blood cell
\end{abstract}


maturation and a high propensity for leukemic transformation. It is furthermore thought to originate in a HSC and to be associated with the accrual of multiple genetic and epigenetic aberrations. This raises the question whether MDS is, in part, related to an inability to adequately cope with DNA damage. Here we discuss the various components of the cellular response to DNA damage. For each component, we evaluate related studies that may shed light on a potential relationship between MDS development and aberrant DNA damage response/repair.

Keywords: myelodysplastic syndrome; hematopoietic stem cells; DNA damage response/repair; aging

\section{Introduction}

Hematopoietic stem cells (HSCs) are responsible for maintaining tissue homeostasis during the lifespan of an organism by generating both new stem cells and progeny that will differentiate into myeloid cells (including leukocytes, erythrocytes and platelets) and lymphoid cells (B and T cells). The HSC compartment is heterogeneous, representing roughly three types of stem cells: those that mostly generate myeloid cells, those that generate mostly lymphoid cells and a third type that generates both lineages somewhat equally. Interestingly, the lifespan of these different HSC types vary, resulting in the disappearance of the latter two HSC types with age [1,2]. Although the reason for the difference in survival of these various HSC types is not clear, it fits with early observations that as we age the relative proportion of myeloid cells increases while that of the lymphoid lineage declines [3-5]. A comparative gene expression study of young vs. old HSCs in mice mirrors this change in myeloid vs. lymphoid cells [4]. Other age-related functional changes in the HSC compartment include a decline in regenerative capacity, i.e., the number of cells (including new stem cells) produced by an individual HSC is lower in old HSCs compared to young HSCs [5-13].

Stem and progenitor cells isolated from older humans and mice show more $\mathrm{H} 2 \mathrm{AX}(\mathrm{H} 2 \mathrm{~A}$ histone family, member X) staining, thought to be indicative of DNA damage, than those isolated from younger individuals [14-16]. These observations, together with comparative gene expression analysis studies in mice, showing that certain DNA repair genes are significantly decreased in old vs. young HSCs [17], suggest that DNA repair functions in HSCs also decline with age. However, two recent studies question this notion [14,18]. Flach et al. showed that H2AX accumulation in old murine HSCs is not associated with DNA damage, but rather with decreased ribosomal biogenesis and possibly gene silencing. However, the same study also showed that old HSCs suffer significantly from replication stress [14], which, if not dealt with appropriately, can lead to permanent DNA damage (reviewed in [19]). It was found that when old HSCs enter the cell cycle, a significantly larger number of chromosomal breaks were detectable in comparison to young HSCs at the same stage, causing them to stay longer in S-phase, presumably for necessary DNA repair. Beerman et al. demonstrated that, indeed, DNA repair pathways are significantly up-regulated in old HSCs as early as $12 \mathrm{~h}$ after they enter the cell cycle [18]. Interestingly, this study and the one from Beerman et al. seem to suggest that age does not affect DNA repair in HSCs, since no significant increases in DNA breaks or gross chromosomal abnormalities could be detected in 
old HSCs (compared to young) after completion of the cell cycle [14,18]. However, the absence of DNA breaks [18] does not provide any information regarding the fidelity of the repair, while karyotyping only detects gross chromosomal rearrangements [20,21] and does not detect small deletions/insertions or single nucleotide perturbations. The latter can occur as a result of deficiencies in DNA double strand break (DSB) repair [22,23] or other types of DNA repair processes, which were not investigated in either study. Thus, more research into this area of HSC aging is desperately needed because the deleterious effects of small mutations in individual genes have been demonstrated to play a significant role in the development and progression of myelodysplastic syndrome (MDS) [24,25]. This HSC disease [26,27] is associated with advanced age [28,29] and will become a serious problem in the Western world as its elderly population grows. This review discusses the various lines of evidence that support the notion that DNA repair defects play a role in the etiology of MDS.

\section{Myelodysplastic Syndrome (MDS) Is a Disease of Genomic Instability}

MDS patients present with signs of a degenerating hematopoietic tissue: chronic fatigue (due to a lack of functional red cells), unexplainable bleedings and bruises (lack of platelets) and/or recurrent infections (lack of leukocytes). MDS is furthermore characterized by genomic instability and a high propensity to progress into acute myeloid leukemia (AML (acute myeloid leukemia); Figure 1) [30].

Genomic instability is a condition in which cells are prone to acquire and accumulate permanent genomic alterations. Examples in MDS patients include the presence of increased numbers of micronuclei in lymphocytes compared to age-matched healthy individuals [31]. Moreover, there is a direct correlation between the frequency of micronuclei observed and MDS severity [31]. Another example is the presence of microsatellite instability (MSI) in patients with therapy-related MDS/AML (t-MDS/AML) (See the section "Mismatch Repair" for more details). Most importantly, 74\%-90\% of MDS patients have mutations in one of $\sim 50$ known cancer genes [24,25]. The top two categories of mutated genes encode regulators of RNA splicing machinery (U2AF35, ZRSR2, SRSF2 and SF3B1) and DNA methylation (TET2, DNMT3A, and IDH1/IDH2). Other important categories of mutated genes include: transcription factors and other transcriptional regulators such as RUNX1, MECOM and CEBPA, and chromatin remodeling proteins such as ASXL1, EZH2, ATRX, KDM6A, CREBBP and EP300. Proteins implicated in tyrosine kinase-associated pathways such as FLT3, CBL, RAS, KIT, CSF1R, PTPN11, as well as JAK2 and MPL (both of which are less common and are often acquired during disease progression) and those that regulate cell cycle and apoptosis, including TP53, IER3 and NPM1 are also often somatically mutated in MDS genomes (reviewed in [32-34]). In addition, cytogenetic abnormalities are found in approximately half of the MDS patients at diagnosis [35]. A considerable proportion of MDS patients present with the same chromosomal abnormalities: $5 q-,-7 / 7 q-$ and +8 are found in 5\%-10\% of de novo MDS [35] and in 40\%-50\% of t-MDS patients [36], whereas uniparental disomy at $4 \mathrm{q}$ is found in $8 \%$ of MDS patients [37]. Less frequent chromosomal abnormalities include $-18 / 18 \mathrm{q}-, 20 \mathrm{q}-,-5,-\mathrm{Y}, \mathrm{t}(17 \mathrm{p}),+21$, inv/t( $3 \mathrm{q}),-13 / 13 \mathrm{q}-$ (present in $3 \%-5 \%$ of MDS patients), and $-21, \mathrm{t}(5 \mathrm{q}),+11, \operatorname{del}(12 p)$, $\operatorname{del}(11 \mathrm{q})$ and $\mathrm{t}(7 \mathrm{q})$ (in $<1 \%$ of patients [32]). In contrast to AML, balanced chromosomal translocations are rarely found in MDS, the most frequently occurring of these, $\operatorname{inv}(3)(\mathrm{q} 21 \mathrm{q} 26.2)$ or $\mathrm{t}(3 ; 3)(\mathrm{q} 21 ; \mathrm{q} 26.2)$, is present in approximately $1 \%$ of patients [38]. 


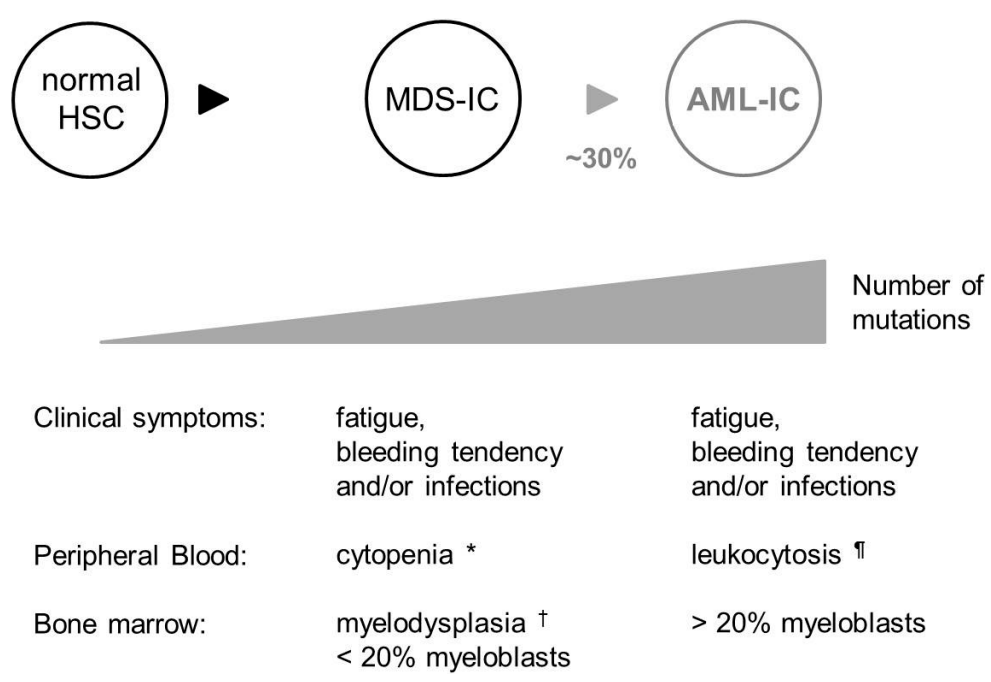

Figure 1. Characteristic features of myelodysplastic syndrome (MDS) in humans. MDS is thought to originate from a mutated Hematopoietic stem cell (HSC). Approximately $30 \%$ of MDS patients progress to AML (acute myeloid leukemia) [30]. With each stage, an increased number of mutations in essential genes can be observed [24,31]; the classic representation of both diseases is depicted. Although MDS and AML have very similar clinical symptoms, they can be distinguished from each other by cell counts in the peripheral blood and pathological review of the bone marrow. Classical MDS is associated with myelodysplasia in the bone marrow and cytopenia in one or more myeloid lineages in the peripheral blood. However, a level of $>20 \%$ myeloblasts in the bone marrow is indicative for AML and excludes the diagnosis of MDS [39,40]. Signs of myelodysplasia can still be present in bone marrow samples of MDS patients that have progressed to AML. In some patients, myelodysplasia and $<20 \%$ myeloblasts in the bone marrow is accompanied with cytosis in one of the peripheral blood lineages; these patients are diagnosed with MDS/MPN (myleoproliferative neoplasm) overlap disease, which is a different disease altogether [41]. MDS-IC, MDS initiating cell; AML-IC, AML initiating cell; * Cytopenia, significantly fewer cells than normal in one of the peripheral blood lineages; ${ }^{\circledR}$ Leukocytosis, significantly more leukocytes than normal in the peripheral blood; ${ }^{\dagger}$ Myelodysplasia, abnormal blood cell morphology.

Importantly, within the same patient, the number of DNA perturbations (mutations and or other DNA abnormalities) often increases as the disease progresses [24,31]. With each additionally required mutation, the risk of leukemic progression, which is associated with a poor prognosis, increases [24].

\section{MDS Is Associated with Excessive DNA Damage}

Genomic instability is directly associated with an inability to cope with damaged DNA, either because of deficient response/repair mechanisms or because of too much DNA damage. Under normal conditions, our genome is constantly exposed to genotoxic stress, either through the formation of genotoxins within the cell (such as reactive oxygen species (ROS) causing oxidative damage), or from the external environment. It is estimated that on average approximately 800 DNA lesions occur per cell per hour [42]. These lesions will be repaired by one of the many DNA repair processes or, when 
the damage is too extensive, cells will be eliminated. When these coping mechanisms are failing, DNA damage beyond normal levels and permanent DNA perturbations become evident.

In MDS patients, excessive DNA damage is commonly observed in the form of oxidative DNA damage. One study showed significantly elevated levels of oxidized nucleotides in bone marrow cells obtained from MDS patients compared to that of healthy controls (9.2\% vs. 1.7\%) [43]. In another, oxidative damage was measured using fluorescence activated cell sorting (FACS) to quantify levels of 8-oxoguanine (8-OG), one of the most common DNA lesions induced by ROS [44]; two thirds of MDS patients had higher 8-OG levels within their leukocytes compared to healthy controls [45]. Using the same methodology, Peddie and colleagues have shown that this damage could only be found within the CD34+ bone marrow cell population from MDS patients (which includes the HSC population), but not in more differentiated CD34- cells, nor in healthy donor marrow cells [46].

In addition to intracellular sources, the external environment also introduces damage into our DNA. Two of the many environmental genotoxins, $\gamma$-radiation and benzene, are well-documented agents that promote the subsequent development of MDS. $\gamma$-Radiation is a high frequency electromagnetic wave produced by the decay of high-energy states in atomic nuclei and can cause many forms of DNA damage through the generation of ROS and DNA DSBs. It is naturally found in cosmic rays; this presents little problem for the general human population since it is largely blocked by the Earth's atmosphere. Yet, radiation poisoning is a concern for astronauts and frequent fliers at high altitudes [47]. People are also at risk if they live near nuclear disasters such as those that occurred in Chernobyl (Ukraine) or in Hiroshima and Nagasaki (Japan). Investigation of clean-up workers from the Chernobyl accident and survivors of the Hiroshima/Nagasaki bombing suggests that radiation poisoning contributed to MDS [48-51].

Benzene $\left(\mathrm{C}_{6} \mathrm{H}_{6}\right)$ is another environmental contaminant that causes DNA damage [52] and for which exposure has been associated with an increase incidence of MDS/AML [53]. It is a colorless volatile liquid hydrocarbon found in coal tar and petroleum and used to make numerous chemical products including detergents, insecticides and motor fuels. Benzene is metabolized to benzene oxide in the liver and then further metabolized to phenol, catechol, hydroquinone and 1,2,4-trihydroxybenzene. These metabolites enter the blood and undergo peroxidase-mediated metabolism in the bone marrow [52], where they are converted into several metabolites, including $p$-benzoquinone, the primary causal agent of myelotoxicity. $p$-Benzoquinone binds to proteins and DNA, where a variety of DNA damage is formed, including DNA DSBs [52,54] and also inhibits DNA topoisomerase II, leading to more DSBs. These were shown to cause illegitimate non-homologous end joining (NHEJ)-mediated recombination at a known breakpoint cluster region of the human AML1 gene [55].

The second largest group of people (after the elderly) that are at risk of developing MDS, are cancer survivors, especially when they have been treated with alkylating agents (such as temozolomide and cyclophosphamide), alone or in combination with topoisomerase II inhibitors (e.g., doxorubicin and etoposide) [56-61] and/or radiation (recently reviewed in [62]). Alkylating agents attach an alkyl group $\left(\mathrm{C}_{n} \mathrm{H}_{2 n+1}\right)$ to DNA, which can be mutagenic or render DNA incapable of properly unwinding for transcription or duplication. The result is cessation of cell growth and apoptosis. However, in some cases, lesions generated by an alkylating agent can be repaired through the combined efforts of various DNA repair pathways (for example, see [63]). Unfortunately, repair of such lesions does not always occur accurately, which can lead to permanent and potentially cancer (MDS)-promoting DNA mutations. 
Topoisomerase II cleaves both strands of DNA to relieve supercoiling and tangling. Etoposide, a topoisomerase II poison, covalently binds topoisomerase II to the enzyme-induced DSBs resulting in a ternary drug-enzyme-DNA complex that blocks the replication fork [64]; thus, etoposide converts topoisomerase II into a poison. This type of damage is different from that caused by $\gamma$-radiation, which simply breaks DNA strands [65]. Although it remains unclear how these ternary drug-enzyme-DNA complexes are identified and processed, etoposide appears to up-regulate NHEJ and p53-dependent cell killing [66].

Taken together, these studies show that both intracellular and extracellular genotoxins are known to cause DNA damage and some of these genotoxins have been proven to play an important role in promoting MDS development.

\section{Cellular Mechanisms to Protect against Permanent DNA Damage}

To protect against permanent DNA damage and its potentially deleterious effects, cells are armed with a plethora of defense mechanisms, including DNA damage sensing mechanisms, cell cycle arrest, apoptosis, senescence and differentiation and DNA repair (Figure 2). Which of these are used depends on the nature and the amount of damage, the cell type and stage of the cell cycle in which the damage occurred [67,68]. Failure to properly execute these processes, may lead to the propagation of cells containing genomic abnormalities. Below follows a more detailed description of the various processes utilized by cells in response to DNA damage. Evidence for a possible link to MDS in humans will be discussed.

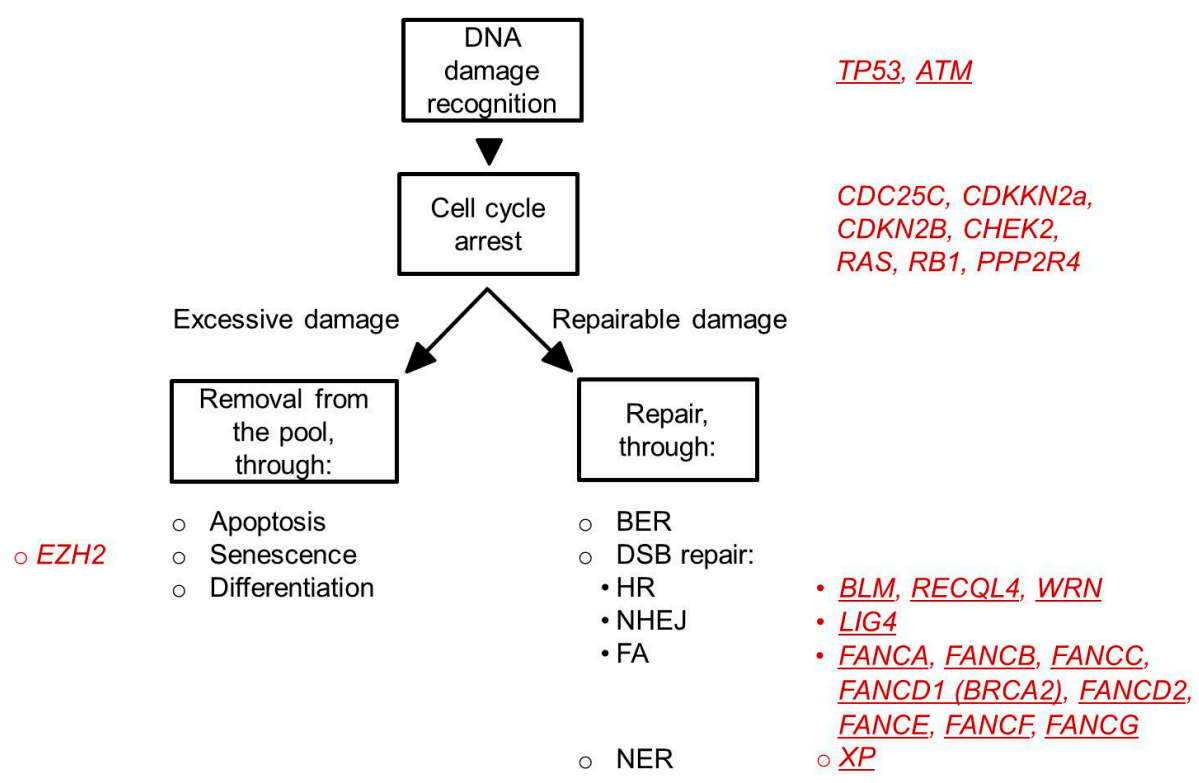

Figure 2. Cellular response to DNA damage. Depicted are the major cellular processes (in black letters) that are initiated after DNA damage. In red are the genes indicated that are related to these processes and that have been found mutated in MDS patients. The underlined symbols indicate genes that are perturbed in hereditary syndromes associated with a high risk of developing MDS (see also Table 1). MDS-associated perturbations in TP53 can be both inherited (Li-Fraumeni syndrome) as well as acquired. 


\subsection{DNA Damage Checkpoints}

To ensure the propagation of cells without genomic aberrations, three major DNA damage checkpoints exist in mammalian cells: the G1/S checkpoint that prevents replication of damaged DNA, the S-phase checkpoint that assesses whether the entire genome has been faithfully replicated before cell division, and the $\mathrm{G} 2 / \mathrm{M}$ checkpoint that prevents propagation of damaged chromosomes into daughter cells through mitosis [69-71]. Activation of one of these checkpoints delays cell cycle progression, allowing repair of the damage through utilization of a variety of damage-specific processes (see below). Genetic or epigenetic alterations of genes involved in these processes, including TP53 [72], RAS [73], CDC25C [74,75], PPP2R4 [74,75], CDKN2B (p15INK4B) [76,77], CDKN2A (p16INK4A) [77], CHEK2 [78] and RB1 [79] have been identified in patients with MDS; they are associated with advanced stages of MDS and leukemic transformation. Patients with mutations in TP53 have a significantly worse prognosis than patients without this mutation [80-85].

If the DNA damage is too extensive, apoptosis, senescence or differentiation will be initiated [86-88] in order that these cells will be purged from the tissue. Several studies have demonstrated that especially in the early stages of MDS, apoptosis is markedly increased. Pro-apoptotic regulators, such as BID and $B A X$ are upregulated in the red cell precursors of MDS patients [89], whereas expression levels of IER3 and $B C L-2$, two anti-apoptotic genes, are decreased [90-92]. Interestingly, apoptosis is an important mechanism utilized by human HSCs to cope with DNA damage [93]. Although apoptosis has not been measured in the MDS-HSCs itself, it is possible that genomically-compromised HSCs are removed from the pool at this phase of the disease. In advanced stages of MDS (with progression to AML, which is associated with a poor prognosis), expression levels of anti-apoptotic genes are increased and the disease reflects a stage of proliferation rather than cell death [90,94]. Cellular senescence is another strategy through which cells can be eliminated from the HSC pool. One of the genes orchestrating this process is $E Z H 2$ (enhancer of zeste homolog 2). EZH2 encodes a histone methyltransferase and is a member of the Polycomb repressive complex 2 that has been shown to catalyze trimethylation of H3K27 (H3K27me3) leading to transcriptional repression. Decreased H3K27me3 is associated with cellular senescence [95]. Although senescence as a HSC-elimination strategy has not yet been demonstrated in humans, gain-of-function mutations of EZH2 are commonly found in MDS and are also associated with a poor prognosis $[96,97]$.

\subsection{DNA Repair Pathways}

\subsubsection{Base Excision Repair (BER)}

This process corrects DNA damage limited to a few bases with an intact secondary DNA structure, resulting from exposure to ROS, radiation or alkylating agents [98-100]. The first stage of BER involves the recognition of damaged or inappropriate bases, and their removal by DNA glycosylases, to leave an abasic site. Several DNA glycosylases have been identified, some of which are strictly lesion-specific, while others are able to recognize multiple lesions. APEX1 (apurinic/apyrimidinic endonuclease-1) then cleaves these sites, creating a single-strand break. Finally, depending on the number of excised nucleotides, the gap is filled by either short-patch BER, in which a single nucleotide 
is replaced using DNA polymerase- $\beta$ and the DNA ligase 3/XRCC1 complex, or by long-patch BER, where 2-10 new nucleotides are inserted using DNA polymerase- $\delta / \varepsilon$, PCNA and DNA ligase 1 [101].

BER is the major repair pathway to correct ROS-mediated DNA damage. Although abnormal expression levels of genes essential to this repair process have been found in MDS patients [45], a direct causal relationship between decreased BER activity and MDS remains to be determined.

\subsubsection{DNA Double Strand Break Repair}

Homologous recombination (HR) and NHEJ are the two major DNA repair pathways in mammalian cells responsible for repairing DSBs that can result from exposure to ROS, radiation and certain types of chemicals [102]. Their utilization is largely dependent upon the phase of the cell cycle in which the damage occurs, and also by the nature of the DNA break. HR mainly functions in late S- or G2-phases of the cell cycle because it requires a homologous chromosome or sister chromatid to serve as the repair template. NHEJ, however, does not need a homologous chromatid template and is therefore active in G1 or G0. [103].

Two major models are used to describe HR: DSB repair and synthesis-dependent strand annealing [104]. These two pathways share the initial steps, namely resection of a DNA DSB so that a 3' single-stranded DNA (ssDNA) overhang becomes available as well as subsequent strand invasion by the 3' ssDNA overhang onto a homologous sequence and DNA synthesis at the invading end. Next, in the DNA DSB repair model, the second DSB end can be captured to form an intermediate with two Holliday junctions. After gap-repair DNA synthesis, using the sister strand as a template and ligation, the structure is resolved at the Holliday junctions in a non-crossover or a crossover mode. In the alternative model, no Holliday junctions are formed and instead, the invading strand is displaced after repair synthesis and reanneals with the single-stranded tail on the other DSB end. Essential proteins for HR include the recombinase RAD51 (strand invasion), BRCA2 (delivers RAD51 to the DNA) and others (extensively reviewed in [104]).

NHEJ is more error-prone than HR due to its ability to process DNA ends prior to ligation, and may generate deletions through removal of nucleotides at damaged ends, or form translocations via ligation of non-matching termini. The classical NHEJ pathway utilizes repair machinery consisting of DNA-PK, XRCC6 (KU70), XRCC5 (KU80), POL IV and DNA ligase 4/XRCC4 complex [105,106]. Depending on whether the single-strand overhangs on the DSB ends are compatible or not, no processing or minimal processing of these ends is performed prior to ligation, leading to accurate or imprecise repair, respectively [105]. There is convincing evidence that the absence or down-regulation of components of the classical NHEJ pathway in leukemia cells induces the activation of an alternative, DNA-PK independent and even more error-prone NHEJ pathway: the microhomology-mediated end joining (MMEJ) pathway [107-109]. This resects nucleotides from the broken ends until a complementary sequence (normally 5-25 base pairs in length [110]), or microhomology, is revealed on both strands [111]. Microhomologous sequences are then utilized for aligning the broken strands before joining. As a result, nucleotides between adjacent microhomologies are deleted. This is in contrast with classical NHEJ which either simply joins the ends and results in no deletion or typically uses microhomologies already exposed in overhangs on the DSB ends (up to 5 base pairs) and result in short deletions (1-4 nucleotides). 
Recent studies in mice have revealed that classical NHEJ is utilized by quiescent HSCs to maintain their genomic integrity (please see [112] for an extensive discussion of this topic). Subsequent work from De Laval et al. showed that thrombopoietin (TPO) signaling, via its receptor (MPL) and downstream activation of ERK and NFKB1, leads to increased levels of phosphorylated IER3. The latter is essential to promote classical, DNA-PK-mediated NHEJ in stem and progenitor cell populations after exposure to ionizing radiation [113,114]. $\gamma$-Radiation induces prolonged genomic instability in HSCs and their progeny [115]. De Laval et al. furthermore demonstrated that this was more severe in HSCs that lacked MPL, while TPO admission to wild-type HSCs prior to radiation exposure diminished long-term genomic instability. Since MDS is a HSC disease, it is possible that this TPO/DNA-PK-mediated NHEJ repair pathway in HSCs is defective and that, as in leukemias, excessive MMEJ is responsible for the genomic instability observed in MDS patients. Although there is no experimental evidence to support this notion in patients yet, it is interesting to note that various IER3 perturbations have been found in MDS patients [92,116] and that Ier3 knock-out mice develop a bone marrow failure syndrome with MDS-like features [117].

The Fanconi anemia (FA) pathway interacts with both the HR and NHEJ pathways. It is particularly important for correcting DNA lesions that stall a replication fork such as interstrand crosslinks. Sixteen FA genes have been identified which are categorized into three groups based on their function $[118,119]$. Group 1 proteins, including, FANCA, B, C, E, F, G, L and FANCM, form a core complex that identifies the lesions and serves as E3 ubiquitin ligase, which monoubiquitinates the group 2 proteins (FANCI and FANCD2). Group 3 proteins, including FANCN, FANCD1 (also known as BRCA2) and FANCJ, mediate crosstalk with other DNA repair pathways including HR and NHEJ [120,121].

Chromosomal deletions and translocations are typical outcomes of aberrantly repaired DSBs. The former is frequently found in MDS, while the latter occurs in t-MDS but rarely in de novo MDS. Mouse studies have demonstrated that misrepair through aberrant NHEJ can also lead to point mutations and small deletions/insertions [23], which would fit with the mutation spectrum found in MDS patients. Indeed, patients with genetic disorders resulting from perturbations in DNA DSB repair genes have an increased incidence of MDS development (Table 1). Most prevalent among these disorders is Fanconi anemia, which is a congenital bone marrow failure syndrome with a hypersensitivity to genotoxic agents, such as mitomycin-C, that create replication fork-blocking lesions. Approximately $20 \%$ of the Fanconi anemia patients develop MDS [122] with a genomic instability that progresses with each state of the disease [123]. Other DSB repair deficiency syndromes with a high incidence of MDS are patients with a defect in a RecQ helicase such as Bloom syndrome [124], Rothmund-Thomson syndrome [125128] and Werner syndrome [129,130].

Acquired perturbations in DSB repair genes or DSB repair activity are not a common finding in MDS patients. This is in contrast to AML, where it is becoming increasingly clear that inefficient DSB repair contributes to disease etiology [131-134]. Possible explanations for this apparent discrepancy may be that DSBs are more likely to be lethal for the cell, or that the consequences of aberrantly repaired DSB are more serious than other types of repair and will lead directly to leukemia. 
Table 1. Increased incidence of MDS in pediatric syndromes associated with defective DNA repair.

\begin{tabular}{|c|c|c|c|c|}
\hline Process Involved & Disease & Gene(s) Involved * & $\begin{array}{c}\text { Incidence of } \\
\text { Disease }\end{array}$ & $\begin{array}{c}\text { Incidence of MDS } \\
\text { in Patients } \\
\end{array}$ \\
\hline $\begin{array}{l}\text { DNA damage response and cell } \\
\text { cycle checkpoint }\end{array}$ & Li-Fraumeni syndrome [135] & TP53 or $C H E K 2$ & 400 Cases reported & 3 Cases reported \\
\hline \multicolumn{5}{|c|}{ DSB repair } \\
\hline \multirow[t]{2}{*}{ Global } & Ataxia Telangiectasia [136] & $A T M$ & $1 / 100,000$ to 40,000 & Not reported \\
\hline & Bloom syndrome [124] & $B L M, B L A P 75 / R M I 1$ & $1 / 48,000$ & 4 Cases reported \\
\hline \multirow[t]{2}{*}{ HR } & Rothmund-Thomson syndrome [125-128] & RECQL4 & 300 Cases reported & 4 Cases reported \\
\hline & Werner syndrome $[129,130]$ & $W R N$ & 1300 Cases reported & 6 Cases reported \\
\hline FA pathway & Fanconi anemia [122] & $F A N C(A-G)$ & $1 / 350,000$ & $20.7 \%$ \\
\hline NHEJ & Lig4 syndrome [137] & LIG4 & Few cases reported & 1 Case reported \\
\hline \multirow[t]{2}{*}{ NER } & Xeroderma Pigmentosa [136] & $X P$ & $1 / 250,000$ & Not reported \\
\hline & Other $\|^{\pi}$ & & & \\
\hline \multirow[t]{2}{*}{ Unclear } & Neurofibromatosis type $1[138]$ & $N F 1$ & $1 / 3500$ & $\begin{array}{l}200-500 \text {-Fold } \\
\text { increase in children }\end{array}$ \\
\hline & Shwachman-Diamond syndrome [139-141] & $S B D S$ & $1 / 50,000$ & $8 \%-33 \%$ \\
\hline Telomere maintenance & Dyskeratosis congenital [142-144] & $\begin{array}{c}D K C 1, N O P 10, N H P 2, \\
\text { TERC, TERT, TINF2 }\end{array}$ & $1 / 1,000,000$ & $4 \%-5 \%$ \\
\hline Oxidative DNA damage repair & Down syndrome [145-147] & Trisomy 21 & $1 / 1000$ to $1 / 650$ & $1 / 1000$ to $1 / 500$ \\
\hline
\end{tabular}

* Genes involved are the genes thought to be directly responsible for the genetic syndrome mentioned in the corresponding "disease" column; ${ }^{\S}$ Most of these diseases present themselves in early childhood. The overall incidence of de novo MDS in children is $\sim 1.8-4$ per 1,000,000 [148]; " Although these diseases are not considered classical DNA repair-deficiency disorders, patients suffering from them have shown either a compromised DNA damage response or increased potential to acquire DNAlesions [139,146,149,150]; Part of this table was published previously in [112]. 


\subsubsection{Mismatch Repair (MMR)}

The MMR pathway corrects base-base mismatches and DNA loops, resulting from aberrant DNA deletions or insertions; when a deletion occurs on the nascent strand after replication, the complementary sequences create a loop on the template strand. Conversely, when an insertion occurs on the nascent strand, the inserted sequence forms this secondary structure. Similar to other excision repair pathways, MMR starts with damage recognition and removal, followed by DNA resynthesis and ligation. In mammalian cells, two heterodimeric complexes have been identified that recognize mismatches: hMutS $\alpha$ (MSH2-MSH6) and hMutS $\beta$ (MSH2-MSH3), which are recruited to the site of damage by PCNA [151]. The endonuclease hMutL $\alpha$ (MLH1-PMS2) then creates a nick at the error site. Upon DNA unwinding by an as yet unknown helicase, $5^{\prime} \rightarrow 3^{\prime}$ exonuclease 1 (EXO1) excises the damaged site and surrounding nucleotides, creating a single-strand gap. This gap is then repaired by the combined action of PCNA/polymerase- $\delta$ complex and DNA ligase I, using the other strand as a template (extensively reviewed in [152]).

Defective MMR in protein coding regions of the genome can result in frameshifts and/or premature stop codons leading to the production of truncated, inactive proteins [153]. Microsatellite regions (i.e., DNA repeats of 1 to 7 base pairs) are non-coding areas of the genome especially prone to replication errors that result in base-base mispairing and DNA loop formation. When MMR functions optimally, the copy number of repeats in such areas is the same in all cells. However, when MMR is impaired, cells begin to display variable numbers of repeats for a given locus, creating so-called microsatellite instability (MSI) regions. MSI regions could be demonstrated in 14\%-64\% of t-MDS/AML patients [154-156], suggesting that MMR deficiency in these patients is a common occurrence. Interestingly, mouse studies showed that MMR-deficient cells have a survival advantage over wild-type cells when exposed to temozolomide [157], a methylating agent used to treat certain brain tumors and known to be associated with an increased risk for t-MDS/AML development [157-159]. Thus, one possible mechanism through which t-MDS/AML develops is selective survival of MMR-deficient cells, allowing those carrying potentially harmful DNA mutations in protein coding regions to propagate.

\subsubsection{Nucleotide Excision Repair (NER)}

The NER pathway, consisting of global genomic repair and transcription-coupled repair [158], removes DNA lesions that affect proper DNA double helix formation (for example, UV-induced thymine dimers and pyrimidine (6-4)-pyrimidone photoproducts, and carcinogen-induced adducts and cross-links [159]). These two pathways differ essentially only in the proteins used to recognize damage [160], namely XPC (xeroderma pigmentosum, complementation group C)-hHR23B-centrin-2 protein complexes [161] and RNA polymerases [162,163], respectively. Following damage recognition, the excision and resynthesis steps appear to be shared by both pathways. ERCC3 (excision repair cross-complementation group 3) and ERCC2 helicases open the DNA structure around damage sites, then ERCC5 and ERCC4-ERCC1 nucleases remove DNA surrounding the sites of damage, leaving a DNA gap of 24-32 nucleotides. This is filled, using the other strand as a template, by DNA Polymerase- $\delta$ or $-\varepsilon$ with the help of proliferating cell nuclear antigen (PCNA), and sealed by DNA ligase (reviewed in [164]). 
Hereditary defects in genes encoding essential NER proteins result in various diseases, including xeroderma pigmentosum (XP), Cockayne syndrome and trichothiodystrophy $[165,166]$. XP (but not the others) is associated with an increased risk of MDS [167,168] (Table 1). Moreover, treatment with Fludarabine, a chemotherapeutic drug that inhibits NER activity, is associated with an increased occurrence of t-MDS/t-AML [169,170].

\section{Conclusions}

The following observations all point to MDS being a disease associated with an inability to adequately respond to DNA damage: (1) Genomic instability is an essential feature of MDS, which worsens as the disease progresses; (2) Hereditary syndromes caused by, or associated with, abnormal DNA repair show a significantly higher risk for MDS development (Table 1); and (3) Exposure to excessive amounts of genotoxins, including chemotherapeutic agents, causes MDS. Yet, aberrations in DNA damage response/repair genes, other than TP53 and some genes involved in DNA damage checkpoints (Figure 2), are rarely found in adult MDS patients. However, MDS is also considered a classical "epigenetic disease" where DNA methylation, histone modification and microRNA expression can be affected (reviewed in [171,172]). Epigenetic changes affect cellular function and this may include DNA repair, although, this has not been investigated yet. Furthermore, many MDS patients have been shown to acquire mutations in genes with a role in epigenesis, including TET2, IDH1, IDH2, ASXL1, EZH2 and $D N M T 3 A$ (as reviewed in [173]). These, however, are not specific to patients with MDS, but are commonly seen in other myeloid malignancies.

Recent experimentation into the relationship between the dose of a genotoxic agent and its mutagenic potential suggest that at low doses, normal cellular processes (DNA repair) are able to fix the damaged DNA; mutagenicity seem to occur only if the damage is beyond a certain threshold [174]. Whether this phenomenon is true for all genotoxins remains to be determined; However, the notion of a threshold effect is of potential interest in light of understanding MDS susceptibility. It is tempting to speculate that a DNA damage threshold exists for each tissue, and that this is specific to each person, depending on their genetic make-up. Gene polymorphisms are likely important determinants of these thresholds; those that significantly lower the threshold in hematopoietic cells are thus expected to be associated with a higher susceptibility to MDS and other hematopoietic malignancies. Aging, with a normally occurring alteration in the epigenetic signature of cells, including HSCs [175], may effectively lower the DNA damage threshold even further. This scenario is not without support. In an excellent review by Guillem and Tormo, many examples are provided that link certain polymorphisms of DNA repair genes to increased risk of developing MDS/AML after chemotherapy [176]. Another example includes the BER-related gene $O G G 1$. A naturally occurring polymorphism of this gene (OGG1-Cys326) was found more often in MDS patients compared to controls [45]. Research into the exact nature of the relationship between gene polymorphisms, DNA damage response/repair and cancer risk is an emerging field, but it may reveal important biomarkers for people at high risk to develop specific age-related cancers such as MDS or MDS secondary to chemotherapy or other genotoxic exposures. 


\section{Acknowledgments}

This publication was supported by funding from the National Institute of Environmental Health Sciences (1RO1ES022054; PH and VIR), Hyundai Hope on Wheels (AJRB and VIR) and the Greehey Children's Cancer Research Institute (VIR).

\section{Author Contributions}

Ting Zhou and Vivienne I. Rebel co-wrote the manuscript. Peishuai Chen and Jian Gu provided guidance on clinical aspects of human MDS, Alexander J. R. Bishop and Paul Hasty on the molecular mechanisms of DNA repair processes and Linda M. Scott on genetic mutations in myeloid neoplasms. All authors participated in revising the manuscript.

\section{Conflicts of Interest}

The authors declare no conflict of interest.

\section{References}

1. Cho, R.H.; Sieburg, H.B.; Muller-Sieburg, C.E. A new mechanism for the aging of hematopoietic stem cells: Aging changes the clonal composition of the stem cell compartment but not individual stem cells. Blood 2008, 111, 5553-5561.

2. Benz, C.; Copley, M.R.; Kent, D.G.; Wohrer, S.; Cortes, A.; Aghaeepour, N.; Ma, E.; Mader, H.; Rowe, K.; Day, C.; et al. Hematopoietic stem cell subtypes expand differentially during development and display distinct lymphopoietic programs. Cell Stem Cell 2012, 10, 273-283.

3. Janzen, V.; Forkert, R.; Fleming, H.E.; Saito, Y.; Waring, M.T.; Dombkowski, D.M.; Cheng, T.; DePinho, R.A.; Sharpless, N.E.; Scadden, D.T. Stem-cell ageing modified by the cyclin-dependent kinase inhibitor p16INK4a. Nature 2006, 443, 421-426.

4. Rossi, D.J.; Bryder, D.; Zahn, J.M.; Ahlenius, H.; Sonu, R.; Wagers, A.J.; Weissman, I.L. Cell intrinsic alterations underlie hematopoietic stem cell aging. Proc. Natl. Acad. Sci. USA 2005, 102, 9194-9199.

5. Sudo, K.; Ema, H.; Morita, Y.; Nakauchi, H. Age-associated characteristics of murine hematopoietic stem cells. J. Exp. Med. 2000, 192, 1273-1280.

6. Chen, J.; Astle, C.M.; Harrison, D.E. Genetic regulation of primitive hematopoietic stem cell senescence. Exp. Hematol. 2000, 28, 442-450.

7. De Haan, G.; Nijhof, W.; van Zant, G. Mouse strain-dependent changes in frequency and proliferation of hematopoietic stem cells during aging: Correlation between lifespan and cycling activity. Blood 1997, 89, 1543-1550.

8. De Haan, G.; van Zant, G. Intrinsic and extrinsic control of hemopoietic stem cell numbers: Mapping of a stem cell gene. J. Exp. Med. 1997, 186, 529-536.

9. Harrison, D.E.; Astle, C.M. Loss of stem cell repopulating ability upon transplantation. Effects of donor age, cell number, and transplantation procedure. J. Exp. Med. 1982, 156, 1767-1779.

10. Harrison, D.E.; Astle, C.M.; Stone, M. Numbers and functions of transplantable primitive immunohematopoietic stem cells. Effects of age. J. Immunol. 1989, 142, 3833-3840. 
11. Kamminga, L.M.; van Os, R.; Ausema, A.; Noach, E.J.; Weersing, E.; Dontje, B.; Vellenga, E.; de Haan, G. Impaired hematopoietic stem cell functioning after serial transplantation and during normal aging. Stem Cells 2005, 23, 82-92.

12. Morrison, S.J.; Qian, D.; Jerabek, L.; Thiel, B.A.; Park, I.K.; Ford, P.S.; Kiel, M.J.; Schork, N.J.; Weissman, I.L.; Clarke, M.F. A genetic determinant that specifically regulates the frequency of hematopoietic stem cells. J. Immunol. 2002, 168, 635-642.

13. Morrison, S.J.; Wandycz, A.M.; Akashi, K.; Globerson, A.; Weissman, I.L. The aging of hematopoietic stem cells. Nat. Med. 1996, 2, 1011-1016.

14. Flach, J.; Bakker, S.T.; Mohrin, M.; Conroy, P.C.; Pietras, E.M.; Reynaud, D.; Alvarez, S.; Diolaiti, M.E.; Ugarte, F.; Forsberg, E.C.; et al. Replication stress is a potent driver of functional decline in ageing haematopoietic stem cells. Nature 2014, 512, 198-202.

15. Rossi, D.J.; Bryder, D.; Seita, J.; Nussenzweig, A.; Hoeijmakers, J.; Weissman, I.L. Deficiencies in DNA damage repair limit the function of haematopoietic stem cells with age. Nature 2007, 447, 725-729.

16. Rube, C.E.; Fricke, A.; Widmann, T.A.; Furst, T.; Madry, H.; Pfreundschuh, M.; Rube, C. Accumulation of DNA damage in hematopoietic stem and progenitor cells during human aging. PLoS One 2011, 6, e17487.

17. Chambers, S.M.; Shaw, C.A.; Gatza, C.; Fisk, C.J.; Donehower, L.A.; Goodell, M.A. Aging hematopoietic stem cells decline in function and exhibit epigenetic dysregulation. PLoS Biol. 2007, 5, e201.

18. Beerman, I.; Seita, J.; Inlay, M.A.; Weissman, I.L.; Rossi, D.J. Quiescent hematopoietic stem cells accumulate DNA damage during aging that is repaired upon entry into cell cycle. Cell Stem Cell 2014, 15, 37-50.

19. Zeman, M.K.; Cimprich, K.A. Causes and consequences of replication stress. Nat. Cell Biol. 2014, $16,2-9$.

20. Hu, L.; Kim, T.M.; Son, M.Y.; Kim, S.A.; Holland, C.L.; Tateishi, S.; Kim, D.H.; Yew, P.R.; Montagna, C.; Dumitrache, L.C.; et al. Two replication fork maintenance pathways fuse inverted repeats to rearrange chromosomes. Nature 2013, 501, 569-572.

21. Kim, T.M.; Ko, J.H.; Hu, L.; Kim, S.A.; Bishop, A.J.; Vijg, J.; Montagna, C.; Hasty, P. RAD51 mutants cause replication defects and chromosomal instability. Mol. Cell. Biol. 2012, 32, 3663-3680.

22. Roberts, S.A.; Strande, N.; Burkhalter, M.D.; Strom, C.; Havener, J.M.; Hasty, P.; Ramsden, D.A. Ku is a 5'-dRP/AP lyase that excises nucleotide damage near broken ends. Nature 2010, 464, 1214-1217.

23. Bennardo, N.; Cheng, A.; Huang, N.; Stark, J.M. Alternative-NHEJ is a mechanistically distinct pathway of mammalian chromosome break repair. PLoS Genet. 2008, 4, e1000110.

24. Papaemmanuil, E.; Gerstung, M.; Malcovati, L.; Tauro, S.; Gundem, G.; van Loo, P.; Yoon, C.J.; Ellis, P.; Wedge, D.C.; Pellagatti, A.; et al. Clinical and biological implications of driver mutations in myelodysplastic syndromes. Blood 2013, 122, 3616-3627.

25. Haferlach, T.; Nagata, Y.; Grossmann, V.; Okuno, Y.; Bacher, U.; Nagae, G.; Schnittger, S.; Sanada, M.; Kon, A.; Alpermann, T.; et al. Landscape of genetic lesions in 944 patients with myelodysplastic syndromes. Leukemia 2014, 28, 241-247. 
26. Chung, Y.J.; Choi, C.W.; Slape, C.; Fry, T.; Aplan, P.D. Transplantation of a myelodysplastic syndrome by a long-term repopulating hematopoietic cell. Proc. Natl. Acad. Sci. USA 2008, 105, 14088-14093.

27. Nilsson, L.; Eden, P.; Olsson, E.; Mansson, R.; Astrand-Grundstrom, I.; Strombeck, B.; Theilgaard-Monch, K.; Anderson, K.; Hast, R.; Hellstrom-Lindberg, E.; et al. The molecular signature of MDS stem cells supports a stem-cell origin of $5 \mathrm{q}$ myelodysplastic syndromes. Blood 2007, 110, 3005-3014.

28. Garcia-Manero, G. Myelodysplastic syndromes: 2012 update on diagnosis, risk-stratification, and management. Am. J. Hematol. 2012, 87, 692-701.

29. Ma, X. Epidemiology of myelodysplastic syndromes. Am. J. Med. 2012, 125, S2-S5.

30. Mufti, G.J. Pathobiology, classification, and diagnosis of myelodysplastic syndrome. Best Pract. Res. Clin. Haematol. 2004, 17, 543-557.

31. Kuramoto, K.; Ban, S.; Oda, K.; Tanaka, H.; Kimura, A.; Suzuki, G. Chromosomal instability and radiosensitivity in myelodysplastic syndrome cells. Leukemia 2002, 16, 2253-2258.

32. Davids, M.S.; Steensma, D.P. The molecular pathogenesis of myelodysplastic syndromes. Cancer Biol. Ther. 2010, 10, 309-319.

33. Greenberg, P.L. Molecular and genetic features of myelodysplastic syndromes. Int. J. Lab. Hematol. 2012, 34, 215-222.

34. Graubert, T.; Walter, M.J. Genetics of myelodysplastic syndromes: New insights. Hematol. Am. Soc. Hematol. Educ. Program. 2011, 543-549.

35. Haase, D.; Germing, U.; Schanz, J.; Pfeilstocker, M.; Nosslinger, T.; Hildebrandt, B.; Kundgen, A.; Lubbert, M.; Kunzmann, R.; Giagounidis, A.A.; et al. New insights into the prognostic impact of the karyotype in MDS and correlation with subtypes: Evidence from a core dataset of 2124 patients. Blood 2007, 110, 4385-4395.

36. Smith, S.M.; le Beau, M.M.; Huo, D.; Karrison, T.; Sobecks, R.M.; Anastasi, J.; Vardiman, J.W.; Rowley, J.D.; Larson, R.A. Clinical-cytogenetic associations in 306 patients with therapy-related myelodysplasia and myeloid leukemia: The University of Chicago series. Blood 2003, 102, 43-52.

37. Mohamedali, A.M.; Smith, A.E.; Gaken, J.; Lea, N.C.; Mian, S.A.; Westwood, N.B.; Strupp, C.; Gattermann, N.; Germing, U.; Mufti, G.J. Novel TET2 mutations associated with UPD4q24 in myelodysplastic syndrome. J. Clin. Oncol. 2009, 27, 4002-4006.

38. Secker-Walker, L.M.; Mehta, A.; Bain, B. Abnormalities of 3q21 and 3q26 in myeloid malignancy: A United Kingdom Cancer Cytogenetic Group study. Br. J. Haematol. 1995, 91, 490-501.

39. Vardiman, J.W. The World Health Organization (WHO) classification of tumors of the hematopoietic and lymphoid tissues: An overview with emphasis on the myeloid neoplasms. Chem. Biol. Interact. 2010, 184, 16-20.

40. Vardiman, J.W.; Thiele, J.; Arber, D.A.; Brunning, R.D.; Borowitz, M.J.; Porwit, A.; Harris, N.L.; le Beau, M.M.; Hellstrom-Lindberg, E.; Tefferi, A.; et al. The 2008 revision of the World Health Organization (WHO) classification of myeloid neoplasms and acute leukemia: Rationale and important changes. Blood 2009, 114, 937-951.

41. Cazzola, M.; Malcovati, L.; Invernizzi, R. Myelodysplastic/myeloproliferative neoplasms. Hematol. Am. Soc. Hematol. Educ. Program. 2011, 2011, 264-272. 
42. Vilenchik, M.M.; Knudson, A.G., Jr. Inverse radiation dose-rate effects on somatic and germ-line mutations and DNA damage rates. Proc. Natl. Acad. Sci. USA 2000, 97, 5381-5386.

43. Novotna, B.; Bagryantseva, Y.; Siskova, M.; Neuwirtova, R. Oxidative DNA damage in bone marrow cells of patients with low-risk myelodysplastic syndrome. Leuk. Res. 2009, 33, 340-343.

44. Amoroso, A.; Concia, L.; Maggio, C.; Raynaud, C.; Bergounioux, C.; Crespan, E.; Cella, R.; Maga, G. Oxidative DNA damage bypass in Arabidopsis thaliana requires DNA polymerase $\lambda$ and proliferating cell nuclear antigen 2. Plant Cell 2011, 23, 806-822.

45. Jankowska, A.M.; Gondek, L.P.; Szpurka, H.; Nearman, Z.P.; Tiu, R.V.; Maciejewski, J.P. Base excision repair dysfunction in a subgroup of patients with myelodysplastic syndrome. Leukemia 2008, 22, 551-558.

46. Peddie, C.M.; Wolf, C.R.; McLellan, L.I.; Collins, A.R.; Bowen, D.T. Oxidative DNA damage in CD34+ myelodysplastic cells is associated with intracellular redox changes and elevated plasma tumour necrosis factor- $\alpha$ concentration. Br. J. Haematol. 1997, 99, 625-631.

47. Bottollier-Depois, J.F.; Chau, Q.; Bouisset, P.; Kerlau, G.; Plawinski, L.; Lebaron-Jacobs, L. Assessing exposure to cosmic radiation on board aircraft. Adv. Space Res. 2003, 32, 59-66.

48. Klymenko, S.; Trott, K.; Atkinson, M.; Bink, K.; Bebeshko, V.; Bazyka, D.; Dmytrenko, I.; Abramenko, I.; Bilous, N.; Misurin, A.; et al. Amll gene rearrangements and mutations in radiation-associated acute myeloid leukemia and myelodysplastic syndromes. J. Radiat. Res. 2005, 46, 249-255.

49. Dyagil, I.; Adam, M.; Beebe, G.W.; Burch, J.D.; Gaidukova, S.N.; Gluzman, D.; Gudzenko, N.; Klimenko, V.; Peterson, L.; Reiss, R.F.; et al. Histologic verification of leukemia, myelodysplasia, and multiple myeloma diagnoses in patients in Ukraine, 1987-1998. Int. J. Hematol. 2002, 76, 55-60.

50. Tsushima, H.; Iwanaga, M.; Miyazaki, Y. Late effect of atomic bomb radiation on myeloid disorders: Leukemia and myelodysplastic syndromes. Int. J. Hematol. 2012, 95, 232-238.

51. Iwanaga, M.; Hsu, W.L.; Soda, M.; Takasaki, Y.; Tawara, M.; Joh, T.; Amenomori, T.; Yamamura, M.; Yoshida, Y.; Koba, T.; et al. Risk of myelodysplastic syndromes in people exposed to ionizing radiation: A retrospective cohort study of Nagasaki atomic bomb survivors. J. Clin. Oncol. 2011, 29, 428-434.

52. Hartwig, A. The role of DNA repair in benzene-induced carcinogenesis. Chem. Biol. Interact. 2010, 184, 269-272.

53. Aul, C.; Bowen, D.T.; Yoshida, Y. Pathogenesis, etiology and epidemiology of myelodysplastic syndromes. Haematologica 1998, 83, 71-86.

54. Ren, X.; Lim, S.; Smith, M.T.; Zhang, L. Werner syndrome protein, WRN, protects cells from DNA damage induced by the benzene metabolite hydroquinone. Toxicol. Sci. 2009, 107, 367-375.

55. Kantidze, O.L.; Razin, S.V. Chemotherapy-related secondary leukemias: A role for DNA repair by error-prone non-homologous end joining in topoisomerase II-Induced chromosomal rearrangements. Gene 2007, 391, 76-79.

56. Baehring, J.M.; Marks, P.W. Treatment-related myelodysplasia in patients with primary brain tumors. Neuro-Oncol. 2012, 14, 529-540.

57. Johnson, B.E.; Mazor, T.; Hong, C.; Barnes, M.; Aihara, K.; McLean, C.Y.; Fouse, S.D.; Yamamoto, S.; Ueda, H.; Tatsuno, K.; et al. Mutational analysis reveals the origin and therapy-driven evolution of recurrent glioma. Science 2014, 343, 189-193. 
58. Smith, R.E. Risk for the development of treatment-related acute myelocytic leukemia and myelodysplastic syndrome among patients with breast cancer: Review of the literature and the National Surgical Adjuvant Breast and Bowel Project experience. Clin. Breast Cancer 2003, 4, 273-279.

59. Au, W.Y.; Ma, S.K.; Wan, T.S.; Man, C.; Kwong, Y.L. Pentasomy 8q in therapy-related myelodysplastic syndrome due to cyclophosphamide therapy for fibrosing alveolitis. Cancer Genet. Cytogenet. 2003, 141, 79-82.

60. Van Leeuwen, F.E. Risk of acute myelogenous leukaemia and myelodysplasia following cancer treatment. Baillière's Clin. Haematol. 1996, 9, 57-85.

61. Winick, N.J.; McKenna, R.W.; Shuster, J.J.; Schneider, N.R.; Borowitz, M.J.; Bowman, W.P.; Jacaruso, D.; Kamen, B.A.; Buchanan, G.R. Secondary acute myeloid leukemia in children with acute lymphoblastic leukemia treated with etoposide. J. Clin. Oncol. 1993, 11, 209-217.

62. Zhang, L.; Wang, S.A. A focused review of hematopoietic neoplasms occurring in the therapy-related setting. Int. J. Clin. Exp. Pathol. 2014, 7, 3512-3523.

63. Marchesi, F.; Turriziani, M.; Tortorelli, G.; Avvisati, G.; Torino, F.; de Vecchis, L. Triazene compounds: Mechanism of action and related DNA repair systems. Pharmacol. Res. 2007, 56, 275-287.

64. Heisig, P. Type II topoisomerases-Inhibitors, repair mechanisms and mutations. Mutagenesis 2009, 24, 465-469.

65. Friedberg, E.C.; Walker, G.C.; Siede, W. DNA Repair and Mutagenesis, 2nd ed.; AMC Press: Washington, DC, USA, 1995.

66. Fan, J.R.; Peng, A.L.; Chen, H.C.; Lo, S.C.; Huang, T.H.; Li, T.K. Cellular processing pathways contribute to the activation of etoposide-induced DNA damage responses. DNA Repair 2008, 7 , $452-463$.

67. Jackson, S.P.; Bartek, J. The DNA-damage response in human biology and disease. Nature 2009, 461, 1071-1078.

68. Essers, J.; Vermeulen, W.; Houtsmuller, A.B. DNA damage repair: Anytime, anywhere? Curr. Opin. Cell Biol. 2006, 18, 240-246.

69. Nigg, E.A. Cyclin-dependent protein kinases: Key regulators of the eukaryotic cell cycle. Bioessays 1995, 17, 471-480.

70. Callegari, A.J.; Kelly, T.J. UV irradiation induces a postreplication DNA damage checkpoint. Proc. Natl. Acad. Sci. USA 2006, 103, 15877-15882.

71. Duensing, A.; Teng, X.; Liu, Y.; Tseng, M.; Spardy, N.; Duensing, S. A role of the mitotic spindle checkpoint in the cellular response to DNA replication stress. J. Cell. Biochem. 2006, 99, 759-769.

72. Christiansen, D.H.; Andersen, M.K.; Pedersen-Bjergaard, J. Mutations with loss of heterozygosity of p53 are common in therapy-related myelodysplasia and acute myeloid leukemia after exposure to alkylating agents and significantly associated with deletion or loss of 5q, a complex karyotype, and a poor prognosis. J. Clin. Oncol. 2001, 19, 1405-1413.

73. Constantinidou, M.; Chalevelakis, G.; Economopoulos, T.; Koffa, M.; Liloglou, T.; Anastassiou, C.; Yalouris, A.; Spandidos, D.A.; Raptis, S. Codon 12 ras mutations in patients with myelodysplastic syndrome: Incidence and prognostic value. Ann. Hematol. 1997, 74, 11-14. 
74. Wei, S.; Chen, X.; Rocha, K.; Epling-Burnette, P.K.; Djeu, J.Y.; Liu, Q.; Byrd, J.; Sokol, L.; Lawrence, N.; Pireddu, R.; et al. A critical role for phosphatase haplodeficiency in the selective suppression of deletion 5q MDS by lenalidomide. Proc. Natl. Acad. Sci. USA 2009, 106, 12974-12979.

75. Sallman, D.A.; Wei, S.; List, A. PP2A: The achilles heal in MDS with 5q deletion. Front. Oncol. 2014, 4, 264.

76. Uchida, T.; Kinoshita, T.; Nagai, H.; Nakahara, Y.; Saito, H.; Hotta, T.; Murate, T. Hypermethylation of the p15INK4B gene in myelodysplastic syndromes. Blood 1997, 90, 1403-1409.

77. Rodrigues, E.F.; Santos-Reboucas, C.B.; Goncalves Pimentel, M.M.; Mencalha, A.L.; Dobbin, J.; da Costa, E.S.; Fernandez Cde, S.; Bouzas, L.F.; Abdelhay, E.; de Souza Fernandez, T. Epigenetic alterations of $p 15(I N K 4 B)$ and $p 16(I N K 4 A)$ genes in pediatric primary myelodysplastic syndrome. Leuk. Lymphoma 2010, 51, 1887-1894.

78. Hofmann, W.K.; Miller, C.W.; Tsukasaki, K.; Tavor, S.; Ikezoe, T.; Hoelzer, D.; Takeuchi, S.; Koeffler, H.P. Mutation analysis of the DNA-damage checkpoint gene CHK2 in myelodysplastic syndromes and acute myeloid leukemias. Leuk. Res. 2001, 25, 333-338.

79. Preudhomme, C.; Vachee, A.; Lepelley, P.; Vanrumbeke, M.; Zandecki, M.; Quesnel, B.; Cosson, A.; Fenaux, P. Inactivation of the retinoblastoma gene appears to be very uncommon in myelodysplastic syndromes. Br. J. Haematol. 1994, 87, 61-67.

80. Bally, C.; Ades, L.; Renneville, A.; Sebert, M.; Eclache, V.; Preudhomme, C.; Mozziconacci, M.J.; de The, H.; Lehmann-Che, J.; Fenaux, P. Prognostic value of TP53 gene mutations in myelodysplastic syndromes and acute myeloid leukemia treated with azacitidine. Leuk. Res. 2014, $38,751-755$.

81. Bejar, R.; Stevenson, K.E.; Caughey, B.; Lindsley, R.C.; Mar, B.G.; Stojanov, P.; Getz, G.; Steensma, D.P.; Ritz, J.; Soiffer, R.; et al. Somatic mutations predict poor outcome in patients with myelodysplastic syndrome after hematopoietic stem-cell transplantation. J. Clin. Oncol. 2014, 32, 2691-2698.

82. Bejar, R.; Lord, A.; Stevenson, K.; Bar-Natan, M.; Perez-Ladaga, A.; Zaneveld, J.; Wang, H.; Caughey, B.; Stojanov, P.; Getz, G.; et al. TET2 mutations predict response to hypomethylating agents in myelodysplastic syndrome patients. Blood 2014, 124, 2705-2712.

83. Saft, L.; Karimi, M.; Ghaderi, M.; Matolcsy, A.; Mufti, G.J.; Kulasekararaj, A.; Gohring, G.; Giagounidis, A.; Selleslag, D.; Muus, P.; et al. p53 protein expression independently predicts outcome in patients with lower-risk myelodysplastic syndromes with del(5q). Haematologica 2014, 99, 1041-1049.

84. Volkert, S.; Kohlmann, A.; Schnittger, S.; Kern, W.; Haferlach, T.; Haferlach, C. Association of the type of $5 q$ loss with complex karyotype, clonal evolution, TP53 mutation status, and prognosis in acute myeloid leukemia and myelodysplastic syndrome. Genes Chromosomes Cancer 2014, 53, $402-410$.

85. Kulasekararaj, A.G.; Smith, A.E.; Mian, S.A.; Mohamedali, A.M.; Krishnamurthy, P.; Lea, N.C.; Gaken, J.; Pennaneach, C.; Ireland, R.; Czepulkowski, B.; et al. TP53 mutations in myelodysplastic syndrome are strongly correlated with aberrations of chromosome 5, and correlate with adverse prognosis. Br. J. Haematol. 2013, 160, 660-672. 
86. D'Adda di Fagagna, F. Living on a break: Cellular senescence as a DNA-damage response. Nat. Rev. Cancer 2008, 8, 512-522.

87. Jeggo, P.A.; Lobrich, M. Contribution of DNA repair and cell cycle checkpoint arrest to the maintenance of genomic stability. DNA Repair 2006, 5, 1192-1198.

88. Wang, J.; Sun, Q.; Morita, Y.; Jiang, H.; Gross, A.; Lechel, A.; Hildner, K.; Guachalla, L.M.; Gompf, A.; Hartmann, D.; et al. A differentiation checkpoint limits hematopoietic stem cell self-renewal in response to DNA damage. Cell 2012, 148, 1001-1014.

89. Tehranchi, R.; Invernizzi, R.; Grandien, A.; Zhivotovsky, B.; Fadeel, B.; Forsblom, A.M.; Travaglino, E.; Samuelsson, J.; Hast, R.; et al. Aberrant mitochondrial iron distribution and maturation arrest characterize early erythroid precursors in low-risk myelodysplastic syndromes. Blood 2005, 106, 247-253.

90. Parker, J.E.; Mufti, G.J.; Rasool, F.; Mijovic, A.; Devereux, S.; Pagliuca, A. The role of apoptosis, proliferation, and the Bcl-2-related proteins in the myelodysplastic syndromes and acute myeloid leukemia secondary to MDS. Blood 2000, 96, 3932-3938.

91. Davis, R.E.; Greenberg, P.L. Bcl-2 expression by myeloid precursors in myelodysplastic syndromes: Relation to disease progression. Leuk. Res. 1998, 22, 767-777.

92. Steensma, D.P.; Neiger, J.D.; Porcher, J.C.; Keats, J.J.; Bergsagel, P.L.; Dennis, T.R.; Knudson, R.A.; Jenkins, R.B.; Santana-Davila, R.; Kumar, R.; et al. Rearrangements and amplification of IER3 (IEX-1) represent a novel and recurrent molecular abnormality in myelodysplastic syndromes. Cancer Res. 2009, 69, 7518-7523.

93. Milyavsky, M.; Gan, O.I.; Trottier, M.; Komosa, M.; Tabach, O.; Notta, F.; Lechman, E.; Hermans, K.G.; Eppert, K.; Konovalova, Z.; et al. A distinctive DNA damage response in human hematopoietic stem cells reveals an apoptosis-independent role for p53 in self-renewal. Cell Stem Cell 2010, 7, 186-197.

94. Parker, J.E.; Fishlock, K.L.; Mijovic, A.; Czepulkowski, B.; Pagliuca, A.; Mufti, G.J. "Low-risk" myelodysplastic syndrome is associated with excessive apoptosis and an increased ratio of pro- $v s$. anti-apoptotic Bcl-2-related proteins. Br. J. Haematol. 1998, 103, 1075-1082.

95. Bracken, A.P.; Kleine-Kohlbrecher, D.; Dietrich, N.; Pasini, D.; Gargiulo, G.; Beekman, C.; Theilgaard-Monch, K.; Minucci, S.; Porse, B.T.; Marine, J.C.; et al. The Polycomb group proteins bind throughout the INK4A-ARF locus and are disassociated in senescent cells. Genes Dev. 2007, $21,525-530$.

96. Wang, J.; Ai, X.; Gale, R.P.; Xu, Z.; Qin, T.; Fang, L.; Zhang, H.; Pan, L.; Hu, N.; Zhang, Y.; et al. TET2, ASXL1 and EZH2 mutations in Chinese with myelodysplastic syndromes. Leuk. Res. 2013, 37, 305-311.

97. Bejar, R.; Stevenson, K.E.; Caughey, B.A.; Abdel-Wahab, O.; Steensma, D.P.; Galili, N.; Raza, A.; Kantarjian, H.; Levine, R.L.; Neuberg, D.; et al. Validation of a prognostic model and the impact of mutations in patients with lower-risk myelodysplastic syndromes. J. Clin. Oncol. 2012, 30, 3376-3382.

98. Dianov, G.L.; Souza-Pinto, N.; Nyaga, S.G.; Thybo, T.; Stevnsner, T.; Bohr, V.A. Base excision repair in nuclear and mitochondrial DNA. Prog. Nucleic Acid Res. Mol. Biol. 2001, 68, 285-297.

99. Almeida, K.H.; Sobol, R.W. A unified view of base excision repair: Lesion-dependent protein complexes regulated by post-translational modification. DNA Repair 2007, 6, 695-711. 
100. Hitomi, K.; Iwai, S.; Tainer, J.A. The intricate structural chemistry of base excision repair machinery: Implications for DNA damage recognition, removal, and repair. DNA Repair (Amst.) 2007, 6, 410-428.

101. Liu, Y.; Prasad, R.; Beard, W.A.; Kedar, P.S.; Hou, E.W.; Shock, D.D.; Wilson, S.H. Coordination of steps in single-nucleotide base excision repair mediated by apurinic/apyrimidinic endonuclease 1 and DNA polymerase beta. J. Biol. Chem. 2007, 282, 13532-13541.

102. Khanna, K.K.; Jackson, S.P. DNA double-strand breaks: Signaling, repair and the cancer connection. Nat. Genet. 2001, 27, 247-254.

103. Kasparek, T.R.; Humphrey, T.C. DNA double-strand break repair pathways, chromosomal rearrangements and cancer. Semin. Cell Dev. Biol. 2011, 22, 886-897.

104. San Filippo, J.; Sung, P.; Klein, H. Mechanism of eukaryotic homologous recombination. Annu. Rev. Biochem. 2008, 77, 229-257.

105. Burma, S.; Chen, B.P.; Chen, D.J. Role of non-homologous end joining (NHEJ) in maintaining genomic integrity. DNA Repair 2006, 5, 1042-1048.

106. Bassing, C.H.; Alt, F.W. The cellular response to general and programmed DNA double strand breaks. DNA Repair 2004, 3, 781-796.

107. Fan, J.; Li, L.; Small, D.; Rassool, F. Cells expressing FLT3/ITD mutations exhibit elevated repair errors generated through alternative NHEJ pathways: Implications for genomic instability and therapy. Blood 2010, 116, 5298-5305.

108. Sallmyr, A.; Tomkinson, A.E.; Rassool, F.V. Up-regulation of WRN and DNA ligase III $\alpha$ in chronic myeloid leukemia: Consequences for the repair of DNA double-strand breaks. Blood 2008, $112,1413-1423$.

109. Greaves, M.F.; Wiemels, J. Origins of chromosome translocations in childhood leukaemia. Nat. Rev. Cancer 2003, 3, 639-649.

110. McVey, M.; Lee, S.E. MMEJ repair of double-strand breaks (director's cut): Deleted sequences and alternative endings. Trends Genet. 2008, 24, 529-538.

111. Kabotyanski, E.B.; Gomelsky, L.; Han, J.O.; Stamato, T.D.; Roth, D.B. Double-strand break repair in Ku86- and XRCC4-deficient cells. Nucleic Acids Res. 1998, 26, 5333-5342.

112. Zhou, T.; Hasty, P.; Walter, C.A.; Bishop, A.J.; Scott, L.M.; Rebel, V.I. Myelodysplastic syndrome: An inability to appropriately respond to damaged DNA? Exp. Hematol. 2013, 41, $665-674$.

113. De Laval, B.; Pawlikowska, P.; Barbieri, D.; Besnard-Guerin, C.; Cico, A.; Kumar, R.; Gaudry, M.; Baud, V.; Porteu, F. Thrombopoietin promotes NHEJ DNA repair in hematopoietic stem cells through specific activation of Erk and NF- $\kappa \mathrm{B}$ pathways and their target, IEX-1. Blood 2014, 123, 509-519.

114. De Laval, B.; Pawlikowska, P.; Petit-Cocault, L.; Bilhou-Nabera, C.; Aubin-Houzelstein, G.; Souyri, M.; Pouzoulet, F.; Gaudry, M.; Porteu, F. Thrombopoietin-increased DNA-PK-dependent DNA repair limits hematopoietic stem and progenitor cell mutagenesis in response to DNA damage. Cell Stem Cell 2013, 12, 37-48.

115. Mohrin, M.; Bourke, E.; Alexander, D.; Warr, M.R.; Barry-Holson, K.; le Beau, M.M.; Morrison, C.G.; Passegue, E. Hematopoietic stem cell quiescence promotes error-prone DNA repair and mutagenesis. Cell Stem Cell 2010, 7, 174-185. 
116. Prall, W.C.; Czibere, A.; Grall, F.; Spentzos, D.; Steidl, U.; Giagounidis, A.A.; Kuendgen, A.; Otu, H.; Rong, A.; Libermann, T.A.; et al. Differential gene expression of bone marrow-derived CD34+ cells is associated with survival of patients suffering from myelodysplastic syndrome. Int. J. Hematol. 2009, 89, 173-187.

117. Ramsey, H.; Zhang, Q.; Brown, D.E.; Steensma, D.P.; Lin, C.P.; Wu, M.X. Stress-induced hematopoietic failure in the absence of immediate early response gene X-1 (IEX-1, IER3). Haematologica 2014, 99, 282-291.

118. Bogliolo, M.; Schuster, B.; Stoepker, C.; Derkunt, B.; Su, Y.; Raams, A.; Trujillo, J.P.; Minguillon, J.; Ramirez, M.J.; Pujol, R.; et al. Mutations in ERCC4, encoding the DNA-repair endonuclease XPF, cause Fanconi anemia. Am. J. Hum. Genet. 2013, 92, 800-806.

119. Crossan, G.P.; Patel, K.J. The Fanconi anaemia pathway orchestrates incisions at sites of crosslinked DNA. J. Pathol. 2012, 226, 326-337.

120. Pace, P.; Mosedale, G.; Hodskinson, M.R.; Rosado, I.V.; Sivasubramaniam, M.; Patel, K.J. Ku70 corrupts DNA repair in the absence of the Fanconi anemia pathway. Science 2010, 329, 219-223.

121. Pichierri, P.; Franchitto, A.; Rosselli, F. BLM and the FANC proteins collaborate in a common pathway in response to stalled replication forks. EMBO J. 2004, 23, 3154-3163.

122. Cioc, A.M.; Wagner, J.E.; MacMillan, M.L.; DeFor, T.; Hirsch, B. Diagnosis of myelodysplastic syndrome among a cohort of 119 patients with fanconi anemia: Morphologic and cytogenetic characteristics. Am. J. Clin. Pathol. 2010, 133, 92-100.

123. Quentin, S.; Cuccuini, W.; Ceccaldi, R.; Nibourel, O.; Pondarre, C.; Pages, M.P.; Vasquez, N.; Dubois d'Enghien, C.; Larghero, J.; Peffault de Latour, R.; et al. Myelodysplasia and leukemia of Fanconi anemia are associated with a specific pattern of genomic abnormalities that includes cryptic RUNX1/AML1 lesions. Blood 2011, 117, e161-e170.

124. Poppe, B.; van Limbergen, H.; van Roy, N.; Vandecruys, E.; de Paepe, A.; Benoit, Y.; Speleman, F. Chromosomal aberrations in Bloom syndrome patients with myeloid malignancies. Cancer Genet. Cytogenet. 2001, 128, 39-42.

125. Ilhan, I.; Arikan, U.; Buyukpamukcu, M. Myelodysplastic syndromes and RTS. Pediatr. Hematol. Oncol. 1996, 13, 197.

126. Narayan, S.; Fleming, C.; Trainer, A.H.; Craig, J.A. Rothmund-Thomson syndrome with myelodysplasia. Pediatr. Dermatol. 2001, 18, 210-212.

127. Pianigiani, E.; de Aloe, G.; Andreassi, A.; Rubegni, P.; Fimiani, M. Rothmund-Thomson syndrome (Thomson-type) and myelodysplasia. Pediatr. Dermatol. 2001, 18, 422-425.

128. Rizzari, C.; Bacchiocchi, D.; Rovelli, A.; Biondi, A.; Cantu'-Rajnoldi, A.; Uderzo, C.; Masera, G. Myelodysplastic syndrome in a child with Rothmund-Thomson syndrome: A case report. J. Pediatr. Hematol. Oncol. 1996, 18, 96-97.

129. Goto, M.; Miller, R.W.; Ishikawa, Y.; Sugano, H. Excess of rare cancers in Werner syndrome (adult progeria). Cancer Epidemiol. Biomark. Prev. 1996, 5, 239-246.

130. Yamamoto, K.; Imakiire, A.; Miyagawa, N.; Kasahara, T. A report of two cases of Werner's syndrome and review of the literature. J. Orthop. Surg. 2003, 11, 224-233.

131. Broberg, K.; Hoglund, M.; Gustafsson, C.; Bjork, J.; Ingvar, C.; Albin, M.; Olsson, H. Genetic variant of the human homologous recombination-associated gene RMI1 (S455N) impacts the risk of AML/MDS and malignant melanoma. Cancer Lett. 2007, 258, 38-44. 
132. Gaymes, T.J.; Mufti, G.J.; Rassool, F.V. Myeloid leukemias have increased activity of the nonhomologous end-joining pathway and concomitant DNA misrepair that is dependent on the Ku70/86 heterodimer. Cancer Res. 2002, 62, 2791-2797.

133. Jacoby, M.A.; de Jesus Pizarro, R.E.; Shao, J.; Koboldt, D.C.; Fulton, R.S.; Zhou, G.; Wilson, R.K.; Walter, M.J. The DNA double-strand break response is abnormal in myeloblasts from patients with therapy-related acute myeloid leukemia. Leukemia 2014, 28, 1242-1251.

134. Seedhouse, C.; Faulkner, R.; Ashraf, N.; Das-Gupta, E.; Russell, N. Polymorphisms in genes involved in homologous recombination repair interact to increase the risk of developing acute myeloid leukemia. Clin. Cancer Res. 2004, 10, 2675-2680.

135. Talwalkar, S.S.; Yin, C.C.; Naeem, R.C.; Hicks, M.J.; Strong, L.C.; Abruzzo, L.V. Myelodysplastic syndromes arising in patients with germline TP53 mutation and Li-Fraumeni syndrome. Arch. Pathol. Lab. Med. 2010, 134, 1010-1015.

136. Gadner, H.; Haas, O.A. Experience in pediatric myelodysplastic syndromes. Hematol. Oncol. Clin. N. Am. 1992, 6, 655-672.

137. Zhang, M.Y.; Keel, S.B.; Walsh, T.; Lee, M.K.; Gulsuner, S.; Watts, A.C.; Pritchard, C.C.; Salipante, S.J.; Jeng, M.R.; Hofmann, I.; et al. Genomic analysis of bone marrow failure and myelodysplastic syndromes reveals phenotypic and diagnostic complexity. Haematologica 2015, $100,42-48$.

138. Stiller, C.A.; Chessells, J.M.; Fitchett, M. Neurofibromatosis and childhood leukaemia/lymphoma: A population-based UKCCSG study. Br. J. Cancer 1994, 70, 969-972.

139. Ball, H.L.; Zhang, B.; Riches, J.J.; Gandhi, R.; Li, J.; Rommens, J.M.; Myers, J.S. Shwachman-Bodian Diamond syndrome is a multi-functional protein implicated in cellular stress responses. Hum. Mol. Genet. 2009, 18, 3684-3695.

140. Ginzberg, H.; Shin, J.; Ellis, L.; Morrison, J.; Ip, W.; Dror, Y.; Freedman, M.; Heitlinger, L.A.; Belt, M.A.; Corey, M.; et al. Shwachman syndrome: Phenotypic manifestations of sibling sets and isolated cases in a large patient cohort are similar. J. Pediatr. 1999, 135, 81-88.

141. Smith, O.P. Shwachman-Diamond syndrome. Semin. Hematol. 2002, 39, 95-102.

142. Gramatges, M.M.; Bertuch, A.A. Short telomeres: From dyskeratosis congenita to sporadic aplastic anemia and malignancy. Transl. Res. 2013, 162, 353-363.

143. Nishio, N.; Kojima, S. Recent progress in dyskeratosis congenita. Int. J. Hematol. 2010, 92, 419-424.

144. Dokal, I. Dyskeratosis congenita in all its forms. Br. J. Haematol. 2000, 110, 768-779.

145. McLean, S.; McHale, C.; Enright, H. Hematological abnormalities in adult patients with Down's syndrome. Ir. J. Med. Sci. 2009, 178, 35-38.

146. Morawiec, Z.; Janik, K.; Kowalski, M.; Stetkiewicz, T.; Szaflik, J.; Morawiec-Bajda, A.; Sobczuk, A.; Blasiak, J. DNA damage and repair in children with Down's syndrome. Mutat. Res. 2008, 637, 118-123.

147. Choi, J.K. Hematopoietic disorders in Down syndrome. Int. J. Clin. Exp. Pathol. 2008, 1, 387-395.

148. Glaubach, T.; Robinson, L.J.; Corey, S.J. Pediatric myelodysplastic syndromes: They do exist! J. Pediatr. Hematol. Oncol. 2014, 36, 1-7. 
149. Pemov, A.; Park, C.; Reilly, K.M.; Stewart, D.R. Evidence of perturbations of cell cycle and DNA repair pathways as a consequence of human and murine NF1-haploinsufficiency. BMC Genomics 2010, 11, 194.

150. Vulliamy, T.J.; Knight, S.W.; Mason, P.J.; Dokal, I. Very short telomeres in the peripheral blood of patients with X-linked and autosomal dyskeratosis congenita. Blood Cells Mol. Dis. 2001, 27, $353-357$.

151. Pluciennik, A.; Dzantiev, L.; Iyer, R.R.; Constantin, N.; Kadyrov, F.A.; Modrich, P. PCNA function in the activation and strand direction of MutL $\alpha$ endonuclease in mismatch repair. Proc. Natl. Acad. Sci. USA 2010, 107, 16066-16071.

152. Buermeyer, A.B.; Deschenes, S.M.; Baker, S.M.; Liskay, R.M. Mammalian DNA mismatch repair. Annu. Rev. Genet. 1999, 33, 533-564.

153. Alemayehu, A.; Fridrichova, I. The MRE11/RAD50/NBS1 complex destabilization in Lynch-syndrome patients. Eur. J. Hum. Genet. 2007, 15, 922-929.

154. Ben-Yehuda, D.; Krichevsky, S.; Caspi, O.; Rund, D.; Polliack, A.; Abeliovich, D.; Zelig, O.; Yahalom, V.; Paltiel, O.; Or, R.; et al. Microsatellite instability and p53 mutations in therapy-related leukemia suggest mutator phenotype. Blood 1996, 88, 4296-4303.

155. Casorelli, I.; Offman, J.; Mele, L.; Pagano, L.; Sica, S.; D’Errico, M.; Giannini, G.; Leone, G.; Bignami, M.; Karran, P. Drug treatment in the development of mismatch repair defective acute leukemia and myelodysplastic syndrome. DNA Repair 2003, 2, 547-559.

156. Olipitz, W.; Hopfinger, G.; Aguiar, R.C.; Gunsilius, E.; Girschikofsky, M.; Bodner, C.; Hiden, K.; Linkesch, W.; Hoefler, G.; Sill, H. Defective DNA-mismatch repair: A potential mediator of leukemogenic susceptibility in therapy-related myelodysplasia and leukemia. Genes Chromosomes Cancer 2002, 34, 243-248.

157. Reese, J.S.; Liu, L.; Gerson, S.L. Repopulating defect of mismatch repair-deficient hematopoietic stem cells. Blood 2003, 102, 1626-1633.

158. Kennedy, R.D.; D’Andrea, A.D. DNA repair pathways in clinical practice: Lessons from pediatric cancer susceptibility syndromes. J. Clin. Oncol. 2006, 24, 3799-3808.

159. Riedl, T.; Hanaoka, F.; Egly, J.M. The comings and goings of nucleotide excision repair factors on damaged DNA. EMBO J. 2003, 22, 5293-5303.

160. Hanawalt, P.C. Subpathways of nucleotide excision repair and their regulation. Oncogene 2002, 21, 8949-8956.

161. Dip, R.; Camenisch, U.; Naegeli, H. Mechanisms of DNA damage recognition and strand discrimination in human nucleotide excision repair. DNA Repair (Amst.) 2004, 3, 1409-1423.

162. Christians, F.C.; Hanawalt, P.C. Lack of transcription-coupled repair in mammalian ribosomal RNA genes. Biochemistry 1993, 32, 10512-10518.

163. Dammann, R.; Pfeifer, G.P. Lack of gene- and strand-specific DNA repair in RNA polymerase III-transcribed human tRNA genes. Mol. Cell. Biol. 1997, 17, 219-229.

164. Fuss, J.O.; Cooper, P.K. DNA repair: Dynamic defenders against cancer and aging. PLoS Biol. 2006, 4, e203.

165. Kraemer, K.H.; Patronas, N.J.; Schiffmann, R.; Brooks, B.P.; Tamura, D.; DiGiovanna, J.J. Xeroderma pigmentosum, trichothiodystrophy and Cockayne syndrome: A complex genotype-phenotype relationship. Neuroscience 2007, 145, 1388-1396. 
166. Cooper, P.K.; Nouspikel, T.; Clarkson, S.G.; Leadon, S.A. Defective transcription-coupled repair of oxidative base damage in Cockayne syndrome patients from XP group G. Science 1997, 275, 990-993.

167. Webb, S. Xeroderma pigmentosum. BMJ 2008, 336, 444-446.

168. Kuehne, T. Pediatric Oncology, 2nd ed.; Imbach, P., Kuehne, T., Arceci, R.J., Eds.; Springer: Berlin, Germany, 2006; pp. 39-40.

169. Carney, D.A.; Westerman, D.A.; Tam, C.S.; Milner, A.; Prince, H.M.; Kenealy, M.; Wolf, M.; Januszewicz, E.H.; Ritchie, D.; Came, N.; et al. Therapy-related myelodysplastic syndrome and acute myeloid leukemia following fludarabine combination chemotherapy. Leukemia 2010, 24, 2056-2062.

170. Tam, C.S.; Seymour, J.F.; Prince, H.M.; Kenealy, M.; Wolf, M.; Januszewicz, E.H.; Westerman, D. Treatment-related myelodysplasia following fludarabine combination chemotherapy. Haematologica 2006, 91, 1546-1550.

171. Issa, J.P. The myelodysplastic syndrome as a prototypical epigenetic disease. Blood 2013, 121, 3811-3817.

172. Vasilatou, D.; Papageorgiou, S.G.; Dimitriadis, G.; Pappa, V. Epigenetic alterations and microRNAs: New players in the pathogenesis of myelodysplastic syndromes. Epigenetics 2013, 8 , 561-570.

173. Shih, A.H.; Abdel-Wahab, O.; Patel, J.P.; Levine, R.L. The role of mutations in epigenetic regulators in myeloid malignancies. Nat. Rev. Cancer 2012, 12, 599-612.

174. Jenkins, G.J.; Zair, Z.; Johnson, G.E.; Doak, S.H. Genotoxic thresholds, DNA repair, and susceptibility in human populations. Toxicology 2010, 278, 305-310.

175. Beerman, I.; Rossi, D.J. Epigenetic regulation of hematopoietic stem cell aging. Exp. Cell Res. 2014, 329, 192-199.

176. Guillem, V.; Tormo, M. Influence of DNA damage and repair upon the risk of treatment related leukemia. Leuk. Lymphoma 2008, 49, 204-217.

(C) 2015 by the authors; licensee MDPI, Basel, Switzerland. This article is an open access article distributed under the terms and conditions of the Creative Commons Attribution license (http://creativecommons.org/licenses/by/4.0/). 